\title{
Variation in Chromosome Number, Karyotype and Nuclear DNA Content of Five Species of Indian Typhonium Schott. (Araceae)—A Medicinally Important Plant
}

\author{
Premananda Das ${ }^{1}$, Satyahari Dey ${ }^{1}$, Anath Bandhu Das ${ }^{2}$, \\ Suprava Mohanty ${ }^{2}$ and HBD Prasad Rao ${ }^{1}$ \\ ${ }^{1}$ Department of Biotechnology, Indian Institute of Technology, Kharagpur 721302, West Bengal, India \\ ${ }^{2}$ Cytogenetics Laboratory, Regional Plant Resource Centre, Bhubaneswar 751015, Orissa, India
}

Received August 14, 2006; accepted September 12, 2006

\begin{abstract}
Summary Detailed karyotype analysis of somatic chromosomes in 5 species of Typhonium Schott. of the family Araceae was carried out for the first time. The chromosome number varied from $2 n=16$ in T. flagelliforme to $2 n=52$ in T. diversifollium. Chromosome number $2 n=18$ and $2 n=26$ in T. trilobatum and T. roxburghii respectively suggest formation of anueploids during speciation. The asymmetric karyotype revealed structural alterations with 2 distinct types of chromosomes (long and very short types) as evident in different species of Typhonium. Significant variations in chromosome size were observed among the studied species. $\mathrm{TF} \%$ revealed sub-metacentric long chromosomes in T. flagelliforme ( $\mathrm{TF}$ value, $33 \%$ ) and metacentric short chromosomes in T. diversifolium (TF value, 41\%). Average chromosome length varied from $2.03 \mu \mathrm{m}$ in T. diversifolium, a high altitude species (5000-7000 ft), to $8.68 \mu \mathrm{m}$ in T. flagelliforme, a low land species (70-250 ft). Significant variations were observed in Interphase Nuclear Volume (INV) which varied from $142.05 \mu \mathrm{m}^{3}$ in T. trilobatum to $335.02 \mu \mathrm{m}^{3}$ in T. flagelliforme; nuclear DNA content varied significantly from $0.199 \mathrm{pg}$ in $T$. diversifolium to $0.833 \mathrm{pg}$ in T. flagelliforme.
\end{abstract}

Key words Chromosome number, Karyotype, Nuclear DNA, Typhonium.

The genus Typhonium Schott. of the family Araceae comprises about 79 species distributed mostly in the south-east Asia and north-east Australia (Hay 1993). In India and Indo-Malesian region, the genus is represented by 16 species (Santapau and Henry 1973). While Typhonium divaricatum (Linn.) Decne occurs mainly in the Penninsular India, T. trilobatum (Linn.) Schott. and T. flagelliforme Decne are the commonly found species in Bengal, Bihar, Orissa and Coromandel coast.

In T. trilobatum, somatic chromosomes $2 n=18$ was reported (Sharma and Mukhopadhyay 1965 ) and $2 n=26$ (Simmonds 1954) were reported with distinctly different morphological characteristics among the ecotypes. Taxonomical grouping of some members of Araceae i.e. genus Sauromatum and Lazarum into Typhonium (Hay 1993) was of interest to us. However such groups based on chromosomal parameters, their karyotypes are not available. This paper deals with detailed investigations on chromosome number their karyotype, interphase nuclear volume (INV) and in situ nuclear DNA content in 5 Indian species of Typhonium may provide insight into chromosome behavior and genomic characteristics during the evolution and speciation in this genus.

Materials and methods

Plants

Tubers of 5 species of Typhonium were collected from varied ecological conditions and main-

*Corresponding author, e-mail: a_b_das@hotmail.com 
Table 1. Nuclear content in 5 species of Typhonium and the ecotypes with the values of other cytological parameters.

\begin{tabular}{|c|c|c|c|c|c|c|c|c|}
\hline Species/Location & $2 n$ & \multicolumn{2}{|c|}{ Karyotype formula } & \multicolumn{2}{|c|}{$\begin{array}{c}\mathrm{TCL} \\
(\mu \mathrm{m} \pm \mathrm{SE})\end{array}$} & $\begin{array}{c}\text { TCV } \\
\left(\mu \mathrm{m}^{3} \pm \mathrm{SE}\right)\end{array}$ & \multicolumn{2}{|c|}{$\begin{array}{c}\mathrm{INV} \\
\left(\mu \mathrm{m}^{3} \pm \mathrm{SE}\right)\end{array}$} \\
\hline T. diversifolium (Kalimpong, WB) & 52 & \multicolumn{2}{|c|}{$6 \mathrm{~A}+4 \mathrm{~B}+36 \mathrm{C}+6 \mathrm{D}$} & \multicolumn{2}{|c|}{$59.39 \pm 2.13$} & $52.78 \pm 1.67$ & \multicolumn{2}{|c|}{$320.45 \pm 2.12$} \\
\hline T. roxburghii (Bhubaneswar, Orissa) & 26 & \multicolumn{2}{|c|}{$4 \mathrm{~A}+2 \mathrm{~B}+16 \mathrm{C}+4 \mathrm{D}$} & \multicolumn{2}{|c|}{$38.54 \pm 2.22$} & $35.65 \pm 3.12$ & \multicolumn{2}{|c|}{$190.22 \pm 3.25$} \\
\hline T. flagelliforme, Eco-I (Daspalla, Orissa) & 16 & \multicolumn{2}{|c|}{$2 \mathrm{~B}+10 \mathrm{C}+4 \mathrm{D}$} & \multicolumn{2}{|c|}{$44.77 \pm 3.21$} & $69.51 \pm 2.44$ & \multicolumn{2}{|c|}{$335.02 \pm 4.56$} \\
\hline T. flagelliforme, Eco-II (Bhubaneswar, Orissa) & 16 & \multicolumn{2}{|c|}{$4 A+6 C+6 D$} & \multicolumn{2}{|c|}{$52.20 \pm 1.20$} & $61.86 \pm 1.98$ & \multicolumn{2}{|c|}{$310.50 \pm 3.46$} \\
\hline T. flagelliforme, Eco-III (Bhubaneswar, Orissa) & 16 & \multicolumn{2}{|c|}{$4 \mathrm{~A}+8 \mathrm{C}+4 \mathrm{D}$} & \multicolumn{2}{|c|}{$50.96 \pm 1.81$} & $68.55 \pm 1.93$ & \multicolumn{2}{|c|}{$322.00 \pm 8.23$} \\
\hline T. trilobatum, Eco-I (BSI, Howrah, WB) & 18 & \multicolumn{2}{|c|}{$2 \mathrm{~A}+2 \mathrm{~B}+10 \mathrm{C}+4 \mathrm{D}$} & \multicolumn{2}{|c|}{$25.21 \pm 2.67$} & $27.44 \pm 2.67$ & \multicolumn{2}{|c|}{$142.05 \pm 8.24$} \\
\hline T. trilobatum, Eco-II (Panskura, WB) & 18 & \multicolumn{2}{|c|}{$4 \mathrm{~A}+8 \mathrm{C}+6 \mathrm{D}$} & \multicolumn{2}{|c|}{$28.55 \pm 2.09$} & $46.03 \pm 2.13$ & \multicolumn{2}{|c|}{$238.75 \pm 7.25$} \\
\hline T. venosum (Renukaji, H.P.) & 18 & \multicolumn{2}{|c|}{$10 C+8 D$} & \multicolumn{2}{|c|}{$44.52 \pm 2.45$} & $50.06 \pm 1.98$ & \multicolumn{2}{|c|}{$270.22 \pm 6.56$} \\
\hline Species/Location & & $\begin{array}{l}\mathrm{DNA} \\
\mathrm{g} \pm \mathrm{SE})\end{array}$ & NSC & $\begin{array}{l}\mathrm{TF} \% \\
(\mu \mathrm{m})\end{array}$ & $\begin{array}{l}\mathrm{ACL} \\
\left(\mu \mathrm{m}^{3}\right)\end{array}$ & $\begin{array}{l}\mathrm{ACV} \\
\left(\mu \mathrm{m}^{3}\right)\end{array}$ & $\begin{array}{l}\text { AINV } \\
(\mathrm{pg})\end{array}$ & ADNA \\
\hline T. diversifolium (Kalimpong, WB) & 10. & $36 \pm 0.08$ & 10 & 41.25 & 2.28 & 2.03 & 6.16 & 0.199 \\
\hline T. roxburghii (Bhubaneswar, Orissa) & & $28 \pm 0.09$ & 6 & 38.54 & 2.35 & 2.74 & 7.31 & 0.318 \\
\hline T. flagelliforme, Eco-I (Daspalla, Orissa) & 12. & $40 \pm 0.12$ & 2 & 33.06 & 5.59 & 8.68 & 20.93 & 0.775 \\
\hline T. flagelliforme, Eco-II (Bhubaneswar, Orissa) & 13. & $38 \pm 0.24$ & 4 & 36.42 & 6.52 & 7.73 & 19.04 & 0.836 \\
\hline T. flagelliforme, Eco-III (Bhubaneswar, Orissa) & 13. & $14 \pm 0.19$ & 4 & 38.90 & 6.37 & 8.56 & 20.12 & 0.821 \\
\hline T. trilobatum, Eco-I (BSI, Howrah, WB) & & $44 \pm 0.34$ & 4 & 37.86 & 2.80 & 3.04 & 7.89 & 0.357 \\
\hline T. trilobatum, Eco-II (Panskura, WB) & & $5 \pm 0.21$ & 4 & 37.36 & 3.71 & 5.11 & 13.26 & 0.392 \\
\hline T. venosum (Renukaji, H.P.) & 11. & $78 \pm 0.35$ & 0 & 36.44 & 4.94 & 5.56 & 15.01 & 0.655 \\
\hline
\end{tabular}

NSC: number of secondary constricted chromosomes, ACL: average chromosome length, ACV: average chromosome volume, AINV: average interphase nuclear volume, ADNA: average DNA amount of chromosome.

tained in the germplasm bank (Table 1). The specimens were identified and deposited in the herbaria of the Botanical Survey of India, Kolkata.

\section{Cytological studies}

Young and healthy root-tips were pretreated in saturated paradichloro-benzene and aesculine mixture for $4 \mathrm{~h}$ at $18^{\circ} \mathrm{C}$ followed by overnight fixation in propionic acid: ethanol $(1: 3)$. Chromosome staining was done in $2 \%$ propionic orcein after cold hydrolysis in $5 \mathrm{~N} \mathrm{HCl}$ for $7 \mathrm{~min}$. Roottips were squashed in $45 \%$ propionic acid. Well-scattered 10 metaphase plates were selected for karyotype analysis of each species. The total chromosome length was ascertained by adding the length of all chromosomes in the karyotype and the total chromosome volume of a karyotype was calculated by applying the formula $\pi r^{2} h$ where ' $r$ ' and ' $h$ ' represent the radius and length of the chromosome, respectively. The form $\%(\mathrm{~F} \%)$ of each chromosome was calculated following the method of Levan et al. (1964). Total form percentage of karyotype was the average of $\mathrm{F} \%$ of a karyotype. Mean values of total chromosome length and total chromosome volume with standard error were calculated.

\section{Interphase Nuclear Volume (INV)}

For scoring of INV data 20 root-tips of about $2.5 \mathrm{~mm}$ length derived from each species were fixed in acetic acid: ethanol $(1: 3)$ for $24 \mathrm{~h}$ at $25^{\circ} \mathrm{C}$ and hydrolyzed in $1 \mathrm{~N} \mathrm{HCl}$ at $60^{\circ} \mathrm{C}$ for $12 \mathrm{~min}$. After thorough washings, root tips were put into Schiff's reagent for $1 \mathrm{~h}$ at $20^{\circ} \mathrm{C}$ and kept in the dark for staining. The root tips were squashed in $45 \%$ acetic acid; 10 randomly selected nuclei were scored from each root tip in 3 replica. Under oil immersion objectives, mean of the 2 diameters of 
Table 2. ANOVA of the nuclear DNA content of different species of Typhonium.

\begin{tabular}{lrrcc}
\hline \hline \multicolumn{1}{c}{ Source } & DF & SS & MS & F \\
\hline Between species & 7 & 22.25 & 3.17 & $8.12^{* *}$ \\
Within species & 72 & 28.24 & 0.39 & - \\
Total & 79 & & & \\
\hline
\end{tabular}

** Significant at $p \geq 0.001, \mathrm{DF}=$ degree of freedom, $\mathrm{SS}=$ sum squares, $\mathrm{MS}=$ mean squares, $\mathrm{F}=$ variance ratio.

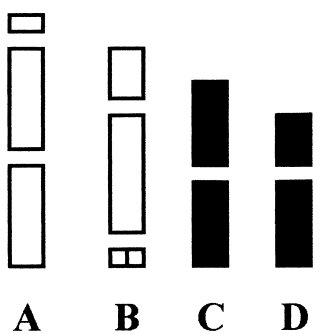

Fig. 1. Standard chromosome types of the members of Typhonium.

each nuclei, obtained by measuring at right angles to each other, was used to calculate the value of INV using the formula, volume $=4 / 3 \pi r^{3}$, with ' $r$ ' is the radius of the nuclei (Das and Mallick 1993).

\section{Cytophotometric estimation of nuclear DNA content}

For Feulgen cytophotometric estimation of 4C DNA content, 10 fixed root-tips from each species/ecotype derived were hydrolyzed in $1 \mathrm{~N} \mathrm{HCl}$ for $12 \mathrm{~min}$ at $60^{\circ} \mathrm{C}$, washed in distilled water and stained in Schiff's reagent for $2 \mathrm{~h}$ at $14^{\circ} \mathrm{C}$. Each root-tip squash was made in $45 \%$ acetic acid separately, 10 scorings were made from each slide and DNA content was estimated from metaphase chromosomes using Nikon Optiphot microspectrophotometer following the method of Sharma and Sharma (1980) with monochromatic light at $550 \mathrm{~nm}$. The experiments were replicated 3 times. In situ DNA were obtained on the basis of optical density which were converted to picograms (pg) using Van’t Hof (1965) 4C nuclear DNA values for Allium cepa cv Deshi (67.1 pg) as standard. To find out the significant differences in the 4C DNA content among different species, if any, ANOVA test (Sokol and Rohlf 1973) was performed. The correlation coefficient analysis of different chromosomal parameters was done to find out the relationship between genomic characteristics of species and ecotypes.

\section{Results}

\section{Chromosome characteristics}

Somatic chromosomes $(2 n=52)$ in T. diversifolium; $(2 n=26)$ in T. roxburghii; $(2 n=16)$ in 3 ecotypes of T. flagelliforme; $(2 n=18)$ in 2 ecotypes of T. trilobatum and $(2 n=18)$ in $T$. venosum were observed. Chromosome length varied significantly from $2.28 \mu \mathrm{m}$ in T. trilobatum (Eco-I) to $6.52 \mu \mathrm{m}$ in $T$. flagelliforme (Eco-II). The smallest chromosomes were observed in $T$. diversifolium and $T$. roxburghii whereas the largest chromosomes were found in T. flagelliforme and T. venosum. On the basis of the data on the length of the chromosomes and the position of the constrictions, 4 chromosome types (A, B, C and D) were recognized (Fig. 1) following the karyotype formula of Levan et al. (1964).

Type A: Large to medium size chromosome with 2 constrictions, primary constriction was at median and secondary constriction was on sub-terminal in positions.

Type B: Large to medium sized chromosome with 2 constrictions, 1 in sub-median and another - the satellite body on the long arm of the chromosome.

Type C: Medium sized chromosome with median primary constriction.

Type D: Medium sized chromosome with sub-median primary constriction.

The karyotype analysis showed distinct variations in the chromosome structure (Table 1 and Figs. 2-8). All the 4 types of chromosomes i.e. A, B, C and D (Fig. 1) were found in the karyotype 


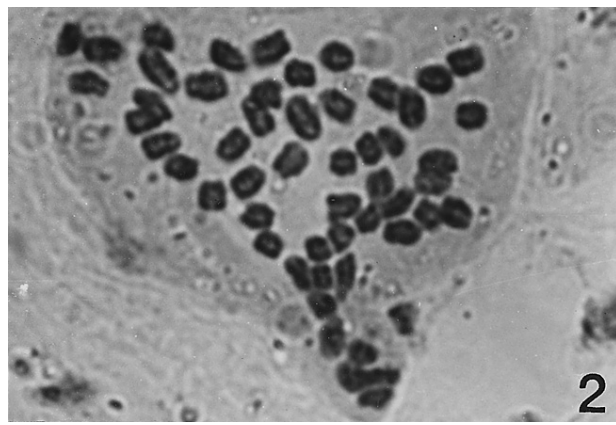

Fig. 2. T. diversifolium $(2 n=52)$

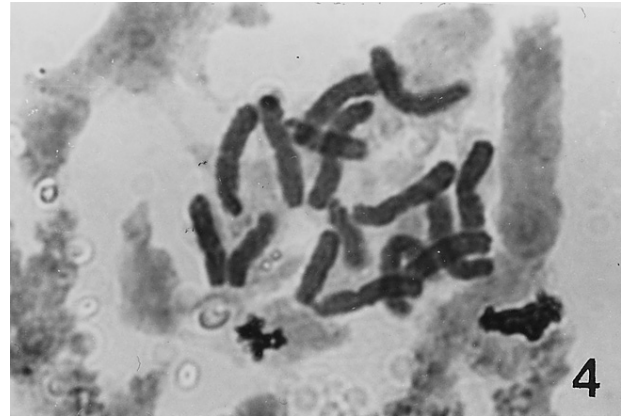

Fig. 4. T. flagelliforme Ecotype-I $(2 n=16)$

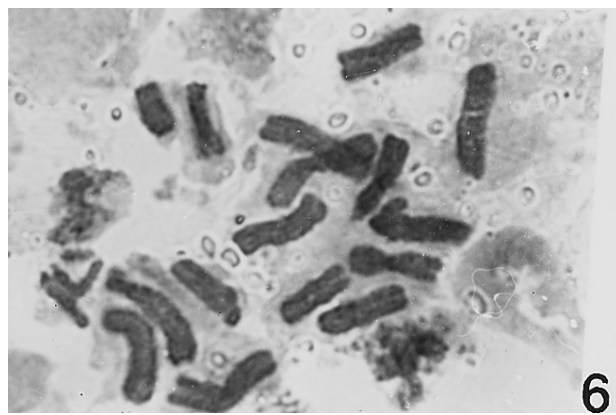

Fig. 6. T. flagelliforme Ecotype-III $(2 n=16)$

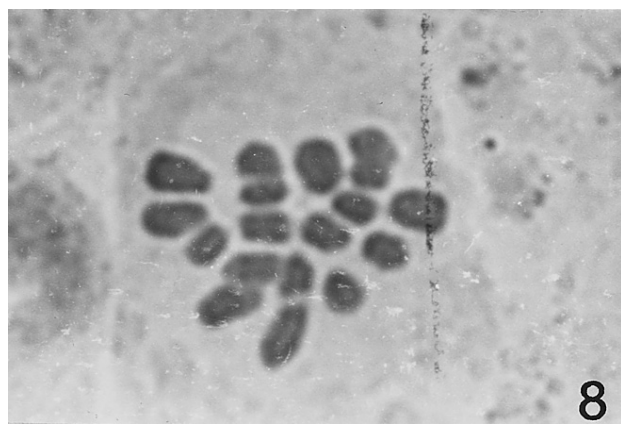

Fig. 8. T. trilobatum Ecotype-II $(2 n=18)$

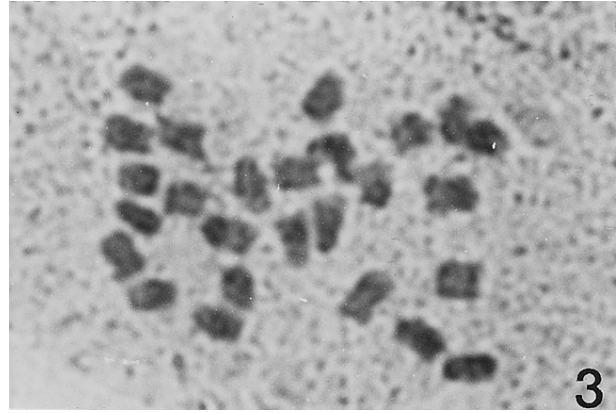

Fig. 3. T. roxburghii $(2 n=26)$

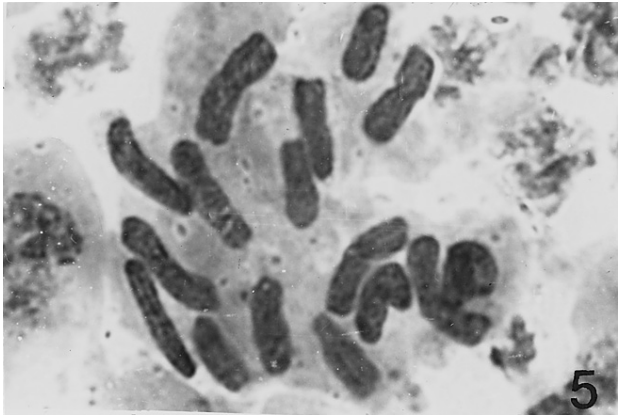

Fig. 5. T. flagelliforme Ecotype-II $(2 n=16)$

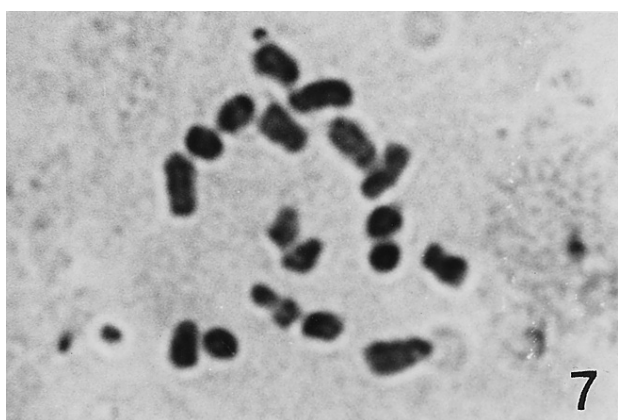

Fig. 7. T. trilobatum Ecotype-I $(2 n=18)$

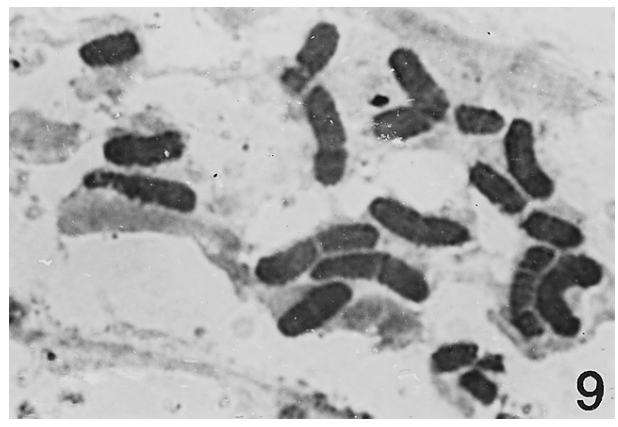

Fig. 9. T. venosum $(2 n=18)$

Figs. 2-9. Somatic chromosomes in different species of Typhonium $\times 2940$. 
of T. diversifolium; T. roxburghii and T. trilobatum (Eco-I). Secondary constricted A and B type chromosomes were missing in T. venosum. T. flagelliforme (Eco-II and Eco-III) collected from Bhubaneswar did not show B type chromosomes and type A chromosome was missing in Eco-I, however, all the ecotypes had 16 chromosomes. The 3 ecotypes of T. flagelliforme differed in their number of $\mathrm{C}$ and D type chromosomes. T. trilobatum (Eco-I and Eco-II) showed equal number of secondary constricted chromosomes; Eco-I had 2 each of A and B type of chromosomes, while Eco-II had only 4 A type chromosomes. The number of secondary constricted chromosomes varied from 2 in T. flagelliforme (Eco-I) to 10 in T. diversifolium. Though median and sub median constricted $\mathrm{C}$ and $\mathrm{D}$ types of chromosomes were found in all the species, their dose differences were the most striking feature; the minimum (6) and the maximum (36) $\mathrm{C}$ type median constricted chromosomes were found in T. flagelliforme (Eco-I) and T. diversifolium respectively; the maximum number (8) of D type chromosomes were present in $T$. venosum. The genomic chromosome length ranged from $25.21 \mu \mathrm{m}$ in T. trilobatum (Eco-I) to $59.39 \mu \mathrm{m}$ in $T$. diversifolium and the chromosome volume ranged from $27.44 \mu \mathrm{m}^{3}$ in T. trilobatum (Eco-I) to $69.51 \mu \mathrm{m}^{3}$ in T. Alagelliforme (Eco-I) (Table 1). The average length of chromosomes varied from $2.28 \mu \mathrm{m}$ in T. diversifolium to $6.52 \mu \mathrm{m}$ in T. flagelliforme (Eco-II). The average chromosome volume ranged from $2.03 \mu \mathrm{m}^{3}$ in $T$. diversifolium to $8.68 \mu \mathrm{m}^{3}$ in T. flagelliforme (Eco-I). The total form percentage (TF\%) varied from 33.06 in T. flagelliforme (Eco-I) to 41.25 in T. diversifolium. Significant variations in chrmosome length, volume and TF\% were observed among the studied species and ecotypes of the genus Typhonium (Table 1).

\section{$4 C$ nuclear DNA amount and INV}

The 4C nuclear DNA amount varied significantly from $6.44 \mathrm{pg}$ in T. trilobatum (Eco-I) to $13.38 \mathrm{pg}$ in T. flagelliforme (Eco-I). Average DNA content per chromosome also varied significantly from species to species (Table 1); minimum DNA $0.199 \mathrm{pg}$ was found in T. diversifolium and the maximum amount $0.836 \mathrm{pg}$ recorded in T. flagelliforme (Eco-II). Analysis of data revealed significant correlation of nuclear DNA content with INV (0.959), with chromosome volume (0.956) and with chromosome length (0.983). Interphase Nuclear Volume (INV) also varied significantly from $142.05 \mu \mathrm{m}^{3}$ in T. trilobatum (Eco-I) to $335.02 \mu \mathrm{m}^{3}$ in T. flagelliforme (Eco-I). The ANOVA and Duncan's multiple range test revealed significant variations in the nuclear DNA content in different species of Typhonium at $1 \%$ level (Table 2).

\section{Discussion}

\section{Cytological and karyotype analysis}

Some species and the ecotypes of Typhonium naturally occurring at varied ecological conditions (tropical coastline to sub-tropical of Himalayas) were studied. The somatic chromosome number $2 n=16$ was found to be constant in all the studied ecotypes of T. flagelliforme reported for the first time; though all the A, B, C type of chromosomes were common, numerical and structural differences in length and centromeric index were found in their respective karyotypes. Equal number of secondary constricted Type A chromosomes present in 2 out of 3 ecotypes confirmed their constant presence without much structural variability. But the number of primary constricted chromosomes i.e. type $\mathrm{B}$ and $\mathrm{C}$ varied among the species leading to minor structural changes in the genomic architecture. The somatic chromosomes $(2 n=18)$ were found in the 2 ecotypes of $T$. trilobatum and $T$. venosum; the size of the chromosome were much larger as compared to those of $T$. diversifolium, and T. roxburghii. Althogh there were very little difference in chromosome size of $T$. roxburghii with $2 n=26$ and $2 n=52$ respectively. Two distinct types of chromosomes based on the size and on the karyotypes were obtained in the studied species. Smaller chromosomes with symmetric or asymmetric karyotypes were the characteristic feature of $T$. diversifolium, $T$. roxburghii and $T$. 
trilobatum; where as, comparatively long and symmetric karyotypes were distinct feature of $T$. flagelliforme and T. venosum.

Evidently, these facts suggests that the structural alterations in chromosomes took place during speciation of the genus Typhonium and eventually got stabilized in evolution. The gradual shifting and alteration of TF\% values from $33.06 \%$ in $T$. flagelliforme Eco-I to $41.25 \%$ in $T$. diversifolium might be due to structural alterations in the genome during adaptation to different ecological conditions as a result of duplication or translocation of chromosomes during meiosis. The higher number of metacentric chromosomes in $T$. diversifolium suggest the genomic characteristics of this species in its cold and high altitude habitat of Kalimpong in West Bengal. The observed highest chromosome volume ( 61.86 to $69.51 \mu \mathrm{m}^{3}$ ) among the 3 ecotypes of $T$. flagelliforme might be due to its different predetermined genomic complements. These results suggest that out breeding among the species in a population might lead to permanent changes in genetic make up. The number of secondary constricted chromosomes also varied from 2 to 10 (Table 1). Evidently, structural changes as well as changes in the amount of heterochromatin played a vital role in inducing differences at species level (Das et al. 1996, Jena et al. 2002).

\section{Nuclear DNA analysis genome size and INV}

The nuclear DNA amount also differed significantly from $6.44 \mathrm{pg}$ to $13.38 \mathrm{pg}$ among 5 species of Typhonium. This diversity in DNA amount had often been attributed to loss or addition of highly repetitive DNA sequences rather than the AT- or GC-rich sequences in a genome (Martel et al. 1997) that reached a certain level and became stabilized during micro-evolution and gradual selection (Price et al. 1980).

The average chromosome length, volume, 4C DNA content and INV varied significantly among the species. The average chromosome length and DNA content ranged from $2.28 \mu \mathrm{m}$ and $0.199 \mathrm{pg}$ in T. diversifolium to $6.52 \mu \mathrm{m}$ and $8.36 \mathrm{pg}$ in Ecotype-II of T. flagelliforme respectively. The volume per chromosome also varied from $2.03 \mu \mathrm{m}^{3}$ in T. diversifolium to $8.68 \mu \mathrm{m}^{3}$ in T. Alagelliforme, Ecotype-I. Correlation coefficient studies revealed significant relationships between average nuclear DNA content and chromosome volume $(r=0.956)$ as well as average chromosome length $(r=0.983)$ and average INV $(r=0.959)$. The 4C DNA values are reported for the first time in these 5 species of Typhonium. However, in the eukaryotic system chromosome volume is determined not only by its DNA, but also by its basic and non-basic proteins. Such variations are similar to other findings in our earlier work on mangroves (Das et al. 1996, Basak et al. 1998, Das et al. 2001, Jena et al. 2002). The diversity of DNA amount has often been attributed to loss or addition of highly repetitive DNA sequences rather than the AT- or GC-reach sequences in a genome (Martel et al. 1997) which after a certain level got stabilized during micro-evolution and gradual selection (Price et al. 1980). Such interspecific variations in DNA amount were not exceptional in angiosperm species (Laurie and Bennett 1985, Rayburn et al. 1989, Tito et al. 1991). Further studies on the phylogeny of the Typhonium using different DNA markers might help in understanding the evolution of these taxa and the genomic in situ hybridization might provide further clues to the evolutionary paths and the ancestry for the adaptive characteristics of the genus Typhonium.

\section{Acknowledgements}

The financial assistance received from Indian National Science Academy, New Delhi by first author is acknowledged.

\section{References}

Basak, U. C., Das, A. B. and Das, P. 1998. In situ quantitization of DNA and karyotype analysis in 4 threatened mangrove 
species found in Bhitarkanika forst of Orissa. Cytobios 93: 147-155.

Das, A. B. and Mallick, R. 1993. Karyotype diversity and interspecific 4C DNA variation in Bupleurum. Biologia P1. 35: $355-365$.

—, Basak, U. C. and Das, P. 1996. Karyotype analysis and 4C nuclear DNA estimation in 3 species of Acanthus, a mangrove associate from coastal Orissa. Cytobios 87: 151-159.

—, Mukherjee, A. K. and Das, P. 2001. Molecular Phylogeny of Heriteria Aiton (Sterculiaceae), a tree mangrove: variations in RAPD markers and nuclear DNA content. Bot. J. Linn. Soc. 136: 221-229.

Jena, S., Sahoo, P., Mohanty, S., Das, A. B. and Das, P. 2002. Karyotype variation and cytophotometric estimation of in situ DNA content in some minor and associate mangroves of India. Cytologia 67: 15-24.

Hay, A. 1993. The genus Typhonium (Araceae-Areae) in Australasia. Blumea 37: 345-376.

Lauria, D. A. and Bennett, M. D. 1985. Nuclear DNA content in the genera Zea and Sorghum; intergeneric and interspecific variation. Heridity 55: 307-313.

Levan, A., Fredya, K. and Sandberg, A. 1964. Nomenclature for centromeric position on chromosome. Heridity 52: 201-220.

Martel, E., Denay, D., Siljakyakovlev, S., Brown, S. and Sarr, A. 1997. Genome size variation and basic chromosome number in pearl millet and 14 related Pennisetum species. J. Hered. 88: 139-143.

Price, H. J., Bachman, K., Cihambers, K. L. and Riggs, J. 1980. Detection of interspecific variation in nuclear DNA content in Microseris douglasii. Bot. Gaz. 141: 195-198.

Rayburn, A. L., Auger, J. A., Benzinger, E. A. and Hepburn, A. G. 1989. Detection of interspecific DNA content variation in Zea mays L. by flow cytometry. J. Exp. Bot. 40: 1179-1183.

Santapau, H. and Henry, 1973. A Dictionary of the flowering plants in India. Publication and Information Directorate, Council of Scientific and Industrial Research, New Delhi, India.

Sharma, A. K. and Mukhopadhyay, S. 1965. Chromosome studies in Typhonium and Arisaema with a view to find out the mode of origin and affinity of the two. Cytologia 30: 58-66.

— and Sharma, A. 1980. Chromosome Techniques: Theory and Practice. Butterworths, London.

Simmonds, N. W. 1954. Chromosome behavior in some tropical plants. Heridity 8: 139-145.

Sokal, P. R. and Rohlf, J. 1973. Introduction to Biostatistics. Freeman, San Francisco.

Tito, C. M., Poggio, L. and Naranjo, C. A. 1991. Cytogenetic studies in the genus Zea 3. DNA content and heterochromatin in species and hybrids. Theoret. Appl. Genet. 85: 58-64.

Van't Hof, J. 1965. Relationships between mitotic cycle duration, S period duration and the average rate of DNA synthesis in the root meristem cells of several plants. Expl. Cell Res. 39: 48. 